\title{
HUBUNGAN SIKAP KERJA DAN MOTIVASI KERJA DENGAN KINERJA GURU BERSERTIFIKASI PADA SDN DI KECAMATAN PANAKKUKANG KOTA MAKASSAR
}

\author{
Muh. Khaedar \\ Program Studi Pendidikan Guru Dasar \\ STKIP Mega Rezky, Jalan Antang Raya No. 45 Kota Makassar \\ khaedarmuh@yahoo.co.id
}

\begin{abstract}
ABSTRAK
Tujuan penelitian ini adalah (1) untuk mengetahui sikap kerja guru, motivasi kerja dan kinerja guru bersertifikasi SDN di kecamatan Panakkukang kota Makassar, (2) untuk mengetahui hubungan sikap kerja dengan kinerja guru bersertifikasi SDN di kecamatan Panakkukang kota Makassar, (3) untuk mengetahui hubungan motivasi kerja dengan kinerja guru bersertifikasi SDN di kecamatan Panakkukang kota Makassar, (4) untuk mengetahui hubungan sikap kerja dan motivasi kerja dengan kinerja guru bersertifikasi SDN di kecamatan Panakkukang kota Makassar. Penelitian ini adalah penelitian adalah pendekatan kuantitatif, jenis penelitian korelasional yaitu dengan ex post facto. Variabel pad penelitian ini yaitu sikap kerja guru $\left(\mathrm{X}_{1}\right)$, motivasi kerja guru $\left(\mathrm{X}_{2}\right)$ dan kinerja guru yang tersertifikasi $(\mathrm{Y})$. Populasi dalam penelitian ini adalah semua guru bersertifikasi di SDN kecamatan Panakkukang kota Makassar, yakni terdiri 60 orang guru yang tersebar di 14 SDN yang terdiri dari 8 gugus. Teknik yang digunakan dalam pengambilan sampel ini adalah Simple Random Sampling, sampel dalam penelitian ini terdiri dari 3 gugus, 7 SDN di Kecamatan Panakukang kota Makassar yang terdiri dari 34 guru yang tersertifikasi. Instrumen pengukuran yang digunakan dalam penelitian ini adalah angket dan telah divalidasi oleh validitor ahli meliputi: Validasi Isi dan Validasi Empirik. Data yang diperoleh dianalisis dengan dua jenis statistik yaitu statistik deskriptif dan statistik inferensial meliputi: Uji Normalitas Data, Uji Homogenitas Data dan Uji Hipotesis.

Hasil penelitian menunjukkan bahwa: (i) gambaran sikap kerja guru, motivasi kerja dan kinerja guru bersertifikasi SDN di kecamatan Panakkukang kota Makassar berada pada kategori baik, (ii) Terdapat hubungan antara sikap kerja guru dengan kinerja guru bersertifikasi di kecamatan panakukang Kota Makassar dengan nilai Sig $(0,000)<\alpha(0,05)$, (iii) terdapat hubungan antara motivasi kerja guru dengan kinerja guru bersertifikasi di kecamatan panakukang Kota Makassar dengan nilai Sig $(0,000)<\alpha(0,05)$ dan (iv) terdapat hubungan sikap kerja dan motivasi kerja guru dengan kinerja guru bersertifikasi di kecamatan panakukang Kota Makassar dengan nilai Sig $(0,000)<\alpha(0,05)$.
\end{abstract}

Kata Kunci: Hubungan, sikap kerja, motivasi kerja dan kinerja guru bersertifikasi. 


\begin{abstract}
This type of research is a pre-experimental study involving one class as an experimental class with the aim of knowing the results of learning mathematics, class VI SD Negeri Bawakaraeng 1 Makassar. The research design used was the one group pretest-posttest, which was a study carried out in the absence of a comparison group but carried out initial tests. The research subjects were class VI students of SD Negeri Bawakaraeng 1 Makassar, which numbered 34 students consisting of 18 female students and 16 male students in the 2017/2018 school year. The data collection technique used is a test of learning outcomes to measure learning outcomes after participating in learning using circuit learning strategies. The data that has been obtained is analyzed using descriptive analysis. The results of the analysis show that: the average pretest score of students' mathematics learning outcomes is 56.13 out of 34 students where only 6 or $17.65 \%$ meet the minimum criteria (KKM) or are in the Very Low category. While the average score of the final test (posttest) of students' mathematics learning outcomes is 79.17 out of 34 students where 29 or $85.29 \%$ meet the minimum completeness criteria (KKM) or are in the moderate category. VI Makassar Bawakaraeng 1 Elementary School can be known from the gain test through the students' average pretest and posttest scores. Gain value obtained is 0.51 and is in the medium category by looking at the N-Gain criteria table. Based on this, it can be seen that the increase in mathematics learning outcomes of students after being taught with the Circuit Learning strategy is in the medium category.
\end{abstract}

Keywords: Learning achievement, Circuit Learning 


\section{PENDAHULUAN}

Pada era globalisasi dewasa ini mutu pendidikan menjadi sangat penting. Bekal pendidikan yang telah dimiliki suatu masyarakat akan berkembang secara baik, dan tidak dapat dipungkiri lagi masyarakat tersebut semakin berkualitas serta mampu bersaing secara kompotitif di era persaingan yang semakin ketat dan keras dalam berbagai sudut aktivitas kehidupan.

Salah satu permasalahan yang dihadapi oleh Bangsa Indonesia adalah rendahnya mutu pendidikan pada setiap jenjang dan satuan pendidikan khususnya pendidikan dasar dan menengah. Untuk itu peningkatan mutu Pendidikan Nasional merupakan kebutuhan yang seharusnya menjadi prioritas utama dalam program pembangunan bangsa.

Berbagai upaya telah dilakukan untuk meningkatkan mutu pendidikan di sekolah, antara lain dengan perbaikan mutu belajar-mengajar. Keberhasilan program pendidikan melalui proses belajar mengajar di sekolah sebagai lembaga pendidikan formal sangat dipengaruhi oleh beberapa faktor antara lain: faktor murid, guru, kurikulum, sarana dan prasarana serta faktor lingkungan.
Pendidikan Nasional dewasa ini menghadapi berbagai persoalan pendidikan yang berat, terutama yang berkaitan dengan kualitas, relevansi dan efisiensi pendidikan.

Permasalahan pendidikan cenderung berkisar pada peningkatan mutu pendidikan, peningkatan efisiensi pengelolaan pendidikan, peningkatan relevansi pendidikan, dan pemerataan pelayanan pendidikan (Mulyasa, 2003: 06).

Semakin baik pendidikan suatu bangsa, semakin baik pula kualitas bangsa itu, itulah asumsi secara umum terhadap program pendidikan suatu bangsa secara faktual pendidikan menggambarkan aktivitas sekelompok orang seperti guru dan tenaga kependidikan lainnya, melaksanakan pendidikan untuk umat manusia baik secara individual maupun kelompok. Kemudian secara perspektif yaitu memberi petunjuk bahwa pendidikan adalah arahan, muatan, pilihan yang ditetapkan sebagai wahana pengembangan masa depan peserta didik yang tidak lepas dari keharusan kontrol manusia sebagai pendidik.

Dengan diberlakukannya Undang-undang guru dan dosen, menunjang sikap profesionalitas dan peningkatan kompetensi guru dalam 
mengajar sebagaimana yang tercantum dalam Undang-undang nomor 14 tahun 2005 pasal 1 ayat 4 tentang guru dan dosen, yang menyebutkan bahwa profesional adalah pekerjaan atau kegiatan yang dilakukan oleh sesseorang dan menjadi sumber penghasilan kehidupan yang memerlukan keahlian, kemahiran atau kecakapan yang memenuhi standar mutu tertentu serta memerlukan pendidikan profesi.

Untuk meningkatkan kualitas peserta didik, seorang pendidik harus memiliki keahlian dan keterampilan dalam proses pembelajaran. Sehingga tercapai mutu pendidikan yang lebih berkualitas yang secara langsung dapat meningkatkan mutu sumber daya manusia di Indonesia, dan tercapainya tujuan pendidikan nasional.

Berdasarkan hasil observasi pada tanggal 23 Mei 2018 yang dilakukan penelitian melalui wawancara dengan beberapa guru bersertifikasi di SDN kecamatan Panakkukang kota Makassar, mereka berasumsi bahwa dalam kinerja guru dalam proses pembelajaran sudah optimal. Namun masih perlu ditingkatkan kualitas dan kapasitasnya pada aspek yang lain selain dari proses pembelajaran di sekolah.
Peningkatan kinerja guru dalam proses pembelajaran memang bukan hal yang sederhana. Banyak faktor yang mempengaruhi kinerja guru. Faktorfaktor tersebut diantaranya adalah penguasaan guru terhadap bahan atau materi yang akan diajarkannya, sikap kerja guru pada profesi yang disandangnya, serta motivasi kerja guru dalam menjalankan tugas dan tanggungjawabnya selaku pendidik.

Dalam hal ini guru sangat berperan dalam menentukan cara yang dianggap efektif untuk melakukan proses pembelajaran serta hal-hal lain yang menjadi indikator tujuan sertifikasi guru SDN di kecamatan Panakkukang kota Makassar. Berhasil tidaknya suatu proses belajar mengajar dapat diketahui dari prestasi belajar atau hasil belajar siswa yang diperoleh. Hasil belajar siswa dikaitkan dengan tinggi rendahnya nilai yang dicapai siswa, daya serap siswa serta prestasi siswa. Berdasarkan latar belakang di atas peneliti akan melakukan penelitian tentang hubungan sikap kerja dan motivasi kerja dengan kinerja guru bersertifikasi SDN di kecamatan Panakkukang Kota Makassar.

Berdasarkan uraian di atas rumusan masalah dalam penelitian ini adalah (1) Bagaimana gambaran sikap 
kerja, motivasi kerja dan kinerja guru bersertifikasi SDN di kecamatan Panakkukang kota Makassar? (2) Apakah ada hubungan sikap kerja dengan kinerja guru bersertifikasi SDN di kecamatan Panakkukang kota Makassar? (3) Apakah ada hubungan motivasi kerja dengan kinerja guru bersertifikasi SDN di kecamatan Panakkukang kota Makassar? (4) Apakah ada hubungan sikap kerja dan motivasi kerja dengan kinerja guru bersertifikasi SDN di kecamatan Panakkukang kota Makassar?.

Tujuan dalam penelitian (1) Untuk mengetahui sikap kerja guru, motivasi kerja dan kinerja guru bersertifikasi SDN di kecamatan Panakkukang kota Makassar. (2) Untuk mengetahui hubungan sikap kerja dengan kinerja guru bersertifikasi SDN di kecamatan Panakkukang kota Makassar. (3) Untuk mengetahui hubungan motivasi kerja dengan kinerja guru bersertifikasi SDN di kecamatan Panakkukang kota Makassar. (4) Untuk mengetahui hubungan sikap kerja dan motivasi kerja dengan kinerja guru bersertifikasi SDN di kecamatan Panakkukang kota Makassar.

\section{METODE PENELITIAN}

\section{Jenis Penelitian}

Pendekatan yang digunakan dalam penelitian ini adalah pendekatan kuantitatif, jenis penelitian korelasional. Dilihat dari jenis data yang ingin dikumpul maka penelitian ini disebut ex post facto.

\section{Variabel Penelitian}

Sugiyono (2015: 3) berpendapat "variabel penelitian adalah suatu atribut atau sifat atau nilai dari orang, objek, atau kegiatan yang mempunyai variasi tertentu yang ditetapkan oleh peneliti untuk dipelajari dan ditarik kesimpulannya. Variabel dalam penelitian ini, yaitu: sikap kerja (X1) dan motivasi kerja (X2) sebagai variabel bebas, kinerja guru (Y) sebagai variabel terikat.

\section{Defenisi Operasional Variabel}

a. Sikap kerja adalah respon yang dilakukan soerang guru terhadap apa yang terjadi di sekitar lingkungan kerjanya baik berupa respon positif maupun respon negatif, seperti perasaan puas atau tidak puas, senang atau tidak senang. Adapun indikator dari sikap kerja antara lain, yaitu: (1) Taat pada peraturan, (2) Senang 
mengerjakan tugas, (3) Bekerja sama dengan teman sejawat (team work), (4) Disiplin, dan

Memprioritaskan pekerjaan.

b. Motivasi kerja adalah dorongan dari dalam dan dari luar diri seorang guru untuk melakukan suatu pekerjaan atau untuk memperoleh imbalan. Berikut beberapa indikator motivasi kerja yaitu:

Mengembangkan karir,

Mengembangkan potensi diri, (3) Menerima kritikan, (4) Bekerja ikhlas, dan (5) Patuh terhadap instruksi atasan.

c. Kinerja guru bersertifikasi meliputi kemampuan, dan hasil yang ditunjukkan oleh seorang guru bersertifikasi dalam melaksanakan proses pembelajaran di sekolah. Diantara indikator-indikatoar kinerja guru bersertifikasi yaitu : (1) Melengkapi perangkat pembelajaran, (2) Terampil dalam proses pembelajaran,

Bersosialisasi dengan lingkungan kerja, dan (4) Aktif dalam tata kelola administrasi.

\section{Populasi dan Sampel}

Populasi adalah kelompok subjek yang akan dikenai generalisasi dari hasil penelitian. Kelompok subjek tersebut harus memiliki karakteristik atau ciriciri yang sama, yaitu: karakteristik berdasarkan golongan/ kepangkatan, tingkat pendidikan terakhir minimal S1 dan bersertifikasi sehingga dapat dibedakan dari kelompok subjek yang lain. Populasi dalam penelitian ini adalah semua guru-guru bersertifikasi yang termasuk ke dalam karakteristik yang telah ditentukan di SDN kecamatan Panakkukang kota Makassar, yakni terdiri 60 orang guru yang ada di kecamatan Panakukang kota Makassar

Sampel merupakan bagian dari populasi, sehingga sampel harus memiliki ciri-ciri atau karakteristik yang dimiliki oleh populasi. Teknik yang digunakan dalam pengambilan sampel ini adalah Simple Random Sampling. Tahapan pengambilan sampel di lakukan secara acak tanpa memperhatikan strata dalam populasi. Sampel dalam penelitian ini terdiri dari 34 guru yang tersertifikasi.

\section{Teknik Pengumpulan Data}

Pengumpulan data adalah suatu prosedur yang sistematis (Siregar, 2013). Sedangkan menurut (Sugiyono, 2015) pengumpulan data bertujuan untuk mendapatkan data yang dibutuhkan dalam suatu penelitian. 
Adapun teknik pengumpulan data yang digunakan dalam penelitian ini adalah:

\section{Kuesioner (Angket)}

Kuesioner

menurut

(Sugiyono,2015) merupakan teknik pengumpulan data yang dilakukan dengan memberikan seperangkat pertanyaan atau pernyataan tertulis kepada responden untuk dijawabnya. Adapun kriteria tiap angket yaitu:

1. Angket untuk mengukur sikap kerja menggunakan skala penilaian likert, setiap item dilengkapi dengan lima pilihan jawaban, yaitu: sangat setuju (SS), setuju (S), ragu-ragu (RR), tidak setuju (TS) dan sangat tidak setuju (STS). Skor dari setiap pernyataan tergantung pada bentuk pernyataan. Untuk pernyataan positif skornya masing-masing adalah $\mathrm{SS}=5, \mathrm{~S}=4, \mathrm{RR}=3, \mathrm{TS}=2$ dan $\mathrm{STS}=1$, sedangkan pada pernyataan negatif skornya masing-masing adalah $\mathrm{SS}=1, \mathrm{~S}=2, \mathrm{RR}=3, \mathrm{TS}=4$ dan $\mathrm{STS}=5$

2. Angket untuk mengukur motivasi kerja menggunakan skala penilaian likert, setiap item dilengkapi dengan lima pilihan jawaban, yaitu: sangat setuju (SS), setuju (S), raguragu (RR), tidak setuju (TS) dan sangat tidak setuju (STS). Skor dari setiap pernyataan tergantung pada bentuk pernyataan. Untuk pernyataan positif skornya masingmasing adalah $\mathrm{SS}=5, \mathrm{~S}=4, \mathrm{RR}=3$, $\mathrm{TS}=2$ dan $\mathrm{STS}=1$, sedangkan pada pernyataan negatif skornya masingmasing adalah $\mathrm{SS}=1, \mathrm{~S}=2, \mathrm{RR}=3$, $\mathrm{TS}=4$ dan $\mathrm{STS}=5$

3. Angket untuk mengukur kinerja guru menggunakan skala penilaian likert, setiap item dilengkapi dengan lima pilihan jawaban, yaitu: sangat setuju (SS), setuju (S), raguragu (RR), tidak setuju (TS) dan sangat tidak setuju (STS). Skor dari setiap pernyataan tergantung pada bentuk pernyataan. Untuk pernyataan positif skornya masingmasing adalah $\mathrm{SS}=5, \mathrm{~S}=4, \mathrm{RR}=3$, $\mathrm{TS}=2$ dan $\mathrm{STS}=1$, sedangkan pada pernyataan negatif skornya masingmasing adalah $\mathrm{SS}=1, \mathrm{~S}=2, \mathrm{RR}=3$, $\mathrm{TS}=4$ dan $\mathrm{STS}=5$.

\section{Instrumen Penelitian}

Instrumen yang digunakan untuk mengukur variabel sikap kerja, motivasi kerja, dan kinerja guru dalam penelitian ini menggunakan skala model likert. Pernyataan sikap dalam skala tersebut dipilih berdasarkan kualitas isi dan analisis statistika terhadap kemampuan pernyataan tersebut dalam 
mengungkap sikap subjek. Skala sikap terdiri dari dua jenis pernyataan, yaitu pernyataan yang bersifat mendukung objek sikap (favorable) dan pernyataan yang bersifat tidak mendukung objek sikap (unfavorable). Pernyataan sikap dalam skala tersebut dipilih berdasarkan kualitas isi dan analisis statistika terhadap kemampuan pernyataan tersebut dalam mengungkap sikap subjek.

\section{Teknik Analisis Data}

Teknik analisis data disesuaikan dengan pernyataan dan hipotesis penelitian. Pernyataan dan hipotesis yang diajukan dalam penelitian ini sesuai dengan analisis kuantitatif yaitu:

\section{a. Analisis Deskriptif}

Analisis deskriptif dilakukan untuk memperoleh gambaran mengenai sikap kerja guru, motivasi kerja guru, dan kinerja guru bersertifikasi agar data tersebut mudah dipahami dan informatif. Analisis deskriptif dilakukan dengan mencari nilai rata-rata hasil angket sikap, motivasi dan kinerja guru bersertifikasi.

\section{b. Analisis Statistik Inferensial}

Pengujian hipotesis dilakukan untuk mengetahui hubungan sikap kerjadan motivasi kerja terhadap kinerja guru bersertifikasi di kecamatan panakukang kota makassar. Pengujian hipotesis menggunakan analisis regresi sederhana maupun ganda. Analisis tersebut menggunakan software SPSS 20,0 for Windows. Kriteria pengujian yang digunakan adalah sig $<\alpha$ dengan taraf $\alpha=0,05$. Sebelum melakukan analisis tersebut, terlebih dahulu melakukan uji prasayarat statistik parametrik, yang meliputi uji normalitas, uji homogenitas, dan uji linearitas.

\section{HASIL PENELITIAN}

a. Gambaran Sikap Kerja guru Tersertifikasi di Kecamatan Panakkukang Kota Makassar

Pengumpulan data dilakukan dengan menggunakan angket sikap kerja yang dibagikan kepada 34 guru yang tersertifikasi dari 7 sekolah dasar yang terdiri dari 3 gugus di Kecamatan Panakukang Kota Makassar.

Berdasarkan kriteria pengkategorian maka diperoleh distribusi frekuensi sikap kerja guru bersertifikasi di kecamatan panakukang Kota Makassar pada tabel berikut: 


\begin{tabular}{cc}
\hline Statistik & $\begin{array}{c}\text { Hasil Angket } \\
\text { Sikap Kerja }\end{array}$ \\
\hline Ukuran sampel & 34 \\
Mean (rata- & 91,32 \\
rata) & \\
Median (nilai & 93,5 \\
tengah) & \\
Mode & 96 \\
Std. Deviasi & 7,96 \\
Varians & 63,32 \\
Rentang & 27 \\
Skor terendah & 76 \\
Skor tertinggi & 103 \\
\hline Jumlah & 3105 \\
\hline
\end{tabular}

Gambar diatas menunjukkan hasil angket sikap kerja guru bersertifikasi di kecamatan panakukang Kota Makassar dengan nilai rata-rata 91,32. Nilai terendah yaitu 76 dan nilai tertinggi 103 dengan standar deviasi 7,96.

\begin{tabular}{|c|c|c|c|}
\hline No & Frekuensi & Persentase & Kategori \\
\hline 1. & 3 & $8,82 \%$ & $\begin{array}{c}\text { Baik } \\
\text { Sekali }\end{array}$ \\
\hline 2. & 26 & $76,47 \%$ & Baik \\
\hline 3. & 5 & $14,71 \%$ & Sedang \\
\hline 4. & 0 & 0 & Kurang \\
\hline 5. & 0 & 0 & Kurang \\
& & & Sekali \\
\hline & 34 & $100 \%$ & \\
\hline
\end{tabular}

Persepsi sikap kerja guru bersertifikasi, 5 (14,71\%) pada kategori sedang, 26 (76,47\%) pada kategori baik, dan $3(8,82 \%)$ pada kategori baik sekali. Dari hasil tersebut dapat dilihat bahwa persentase tertinggi ada pada kategori baik dengan frekuensi 26 sehingga dapat dikemukakan bahwa sikap kerja guru bersertifikasi se-Kecamatan panakukang kota makassar berada pada kategori baik.

\section{b. Gambaran Motivasi Kerja guru Tersertifikasi di Kecamatan Panakkukang Kota Makassar}

Pengumpulan data dilakukan dengan menggunakan angket motivasi kerja yang dibagikan kepada 34 guru yang tersertifikasi dari 7 sekolah dasar yang terdiri dari 3 gugus di Kecamatan Panakukang Kota Makassar.

Berdasarkan kriteria pengkategorian maka diperoleh distribusi frekuensi motivasi kerja guru bersertifikasi di kecamatan panakukang Kota Makassar pada tabel berikut:

\begin{tabular}{cc}
\hline Statistik & $\begin{array}{c}\text { Hasil Angket } \\
\text { Motivasi Kerja }\end{array}$ \\
\hline $\begin{array}{c}\text { Ukuran sampel } \\
\text { Mean (rata- } \\
\text { rata) }\end{array}$ & 34 \\
\end{tabular}




\begin{tabular}{cc} 
Median (nilai & 93,71 \\
tengah) & \\
Mode & 93 \\
Std. Deviasi & 8,95 \\
Varians & 80 \\
Rentang & 42 \\
Skor terendah & 78 \\
Skor tertinggi & 120 \\
\hline Jumlah & 3187 \\
\hline
\end{tabular}

Gambar diatas menunjukkan hasil angket motivasi kerja guru bersertifikasi di kecamatan panakukang Kota Makassar dengan nilai rata-rata 93,74 . Nilai terendah yaitu 78 dan nilai tertinggi 120 dengan standar deviasi 8,95 .

\begin{tabular}{|c|c|c|c|}
\hline No & Frekuensi & Persentase & Kategori \\
\hline 1. & 4 & $11,76 \%$ & $\begin{array}{c}\text { Baik } \\
\text { Sekali }\end{array}$ \\
\hline 2. & 26 & $76,47 \%$ & Baik \\
\hline 3. & 4 & $11,76 \%$ & Sedang \\
\hline 4. & 0 & 0 & Kurang \\
\hline 5. & 0 & 0 & $\begin{array}{c}\text { Kurang } \\
\text { Sekali }\end{array}$ \\
\hline & 34 & $100 \%$ & \\
\hline
\end{tabular}

Persepsi Motivasi kerja guru bersertifikasi, 4 (11,76\%) pada kategori sedang, 26 (76,47\%) pada kategori baik, dan $4(11,76 \%)$ pada kategori baik sekali. Dari hasil tersebut dapat dilihat bahwa persentase tertinggi ada pada kategori baik dengan frekuensi 26 sehingga dapat dikemukakan bahwa motivasi kerja guru bersertifikasi seKecamatan panakukang kota makassar berada pada kategori baik.

\section{c. Gambaran Kinerja guru Tersertifikasi di Kecamatan Panakkukang Kota Makassar}

Pengumpulan data dilakukan dengan menggunakan angket kinerja guru bersertifikasi yang dibagikan kepada 34 guru yang tersertifikasi dari 7 sekolah dasar yang terdiri dari 3 gugus di Kecamatan Panakukang Kota Makassar.

Berdasarkan kriteria pengkategorian maka diperoleh distribusi frekuensi kinerja guru bersertifikasi di kecamatan panakukang Kota Makassar pada tabel berikut:

\begin{tabular}{cc}
\hline Statistik & $\begin{array}{c}\text { Hasil Angket } \\
\text { Kinerja }\end{array}$ \\
\hline Ukuran sampel & 34 \\
Mean (rata-rata) & 96,26 \\
Median (nilai & 96 \\
tengah) & \\
Mode & 98
\end{tabular}

Std. Deviasi $\quad 11,17$ 


\begin{tabular}{cc} 
Varians & 124 \\
Rentang & 44 \\
Skor terendah & 78 \\
Skor tertinggi & 122 \\
\hline Jumlah & 3273 \\
\hline
\end{tabular}

Gambar diatas menunjukkan hasil angket kinerja guru bersertifikasi di kecamatan panakukang Kota Makassar dengan nilai rata-rata 92,26. Nilai terendah yaitu 78 dan nilai tertinggi 122 dengan standar deviasi 11,17 .

\begin{tabular}{|c|c|c|c|}
\hline No & Frekuensi & Persentase & Kategori \\
\hline 1. & 8 & $23,53 \%$ & $\begin{array}{c}\text { Baik } \\
\text { Sekali }\end{array}$ \\
\hline 2. & 22 & $64,71 \%$ & Baik \\
\hline 3. & 4 & $11,76 \%$ & Sedang \\
\hline 4. & 0 & 0 & Kurang \\
\hline 5. & 0 & 0 & Kurang \\
& & & Sekali \\
\hline & 34 & $100 \%$ & \\
\hline
\end{tabular}

Persepsi sikap kerja guru bersertifikasi, 4 (11,76\%) pada kategori sedang, 22 (64,71\%) pada kategori baik, dan 8 (23,53\%) pada kategori baik sekali. Dari hasil tersebut dapat dilihat bahwa persentase tertinggi ada pada kategori baik dengan frekuensi 22 sehingga dapat dikemukakan bahwa kinerja guru bersertifikasi seKecamatan panakukang kota makassar berada pada kategori baik.

\section{d. Hubungan Sikap Kerja Guru dengan Kinerja guru Tersertifikasi di Kecamatan Panakkukang Kota Makassar}

Berdasarkan hasil yang diperoleh pada Tabel 4.7 dapat dilihat bahwa hubungan antara sikap kerja dengan kinerja guru dilakukan dengan membandingkan nilai signifikansi (sig) dengan nilai alpha $(\alpha)$ Kriteria pengujian apabila nilai Sig $<\alpha(0,05)$ maka $\mathrm{H}_{0}$ ditolak. Hasil analisis memperoleh nilai Sig 0,000, sesuai dengan kriteria yang ditentukan Sig $(0,000)<\alpha(0,05)$ sehingga $H_{0}$ ditolak dan $\mathrm{H}_{1}$ diterima. Hal ini menunjukkan terdapat hubungan antara sikap kerja guru dengan kinerja guru bersertifikasi di kecamatan panakukang Kota Makassar.

\section{e. Hubungan Motivasi Kerja Guru dengan Kinerja guru Tersertifikasi di Kecamatan Panakkukang Kota Makassar}

Berdasarkan hasil yang diperoleh pada Tabel 4.8 dapat dilihat bahwa hubungan antara motivasi kerja dengan 
kinerja guru dilakukan dengan membandingkan nilai signifikansi (sig) dengan nilai alpha $(\alpha)$ Kriteria pengujian apabila nilai Sig $<\alpha(0,05)$ maka $\mathrm{H}_{0}$ ditolak. Hasil analisis memperoleh nilai Sig 0,000 , sesuai dengan kriteria yang ditentukan Sig $(0,000)<\alpha(0,05)$ sehingga $\mathrm{H}_{0}$ ditolak dan $\mathrm{H}_{1}$ diterima. Hal ini menunjukkan terdapat hubungan antara motivasi kerja guru dengan kinerja guru bersertifikasi di kecamatan panakukang Kota Makassar.

\section{f. Hubungan Sikap Kerja dan Motivasi Kerja Guru dengan Kinerja guru Tersertifikasi di Kecamatan Panakkukang Kota Makassar}

Berdasarkan hasil yang diperoleh pada Tabel 4.9 dapat dilihat bahwa hubungan sikap kerja dan motivasi kerja dengan kinerja guru dilakukan dengan membandingkan nilai signifikansi (sig) dengan nilai alpha $(\alpha)$. Kriteria pengujian apabila nilai $\operatorname{Sig}<\alpha$ $(0,05)$ maka $\mathrm{H}_{0}$ ditolak. Hasil analisis memperoleh nilai Sig 0,000, sesuai dengan kriteria yang ditentukan Sig $(0,000)<\alpha(0,05)$ sehingga $\mathrm{H}_{0}$ ditolak dan $\mathrm{H}_{1}$ diterima. Hal ini menunjukkan terdapat hubungan sikap kerja dan motivasi kerja guru dengan kinerja guru bersertifikasi di kecamatan panakukang Kota Makassar.

Temuan penelitian ini menunjukkan bahwa terdapat hubungan antara sikap kerja dan motivasi kerja dengan kinerja guru bersertifikasi di kecamatan panakukang kota makassar. Hubungan tersebut diduga disebabkan oleh:

1. Guru yang tersertifikasi memiliki sikap kerja yang baik, dengan sikap kerja yang baik terdapat hubungan kinerja yang baik pula, hal ini sesuai dengan faktor yang mendukung terhadap sikap kerja yang mereka miliki. Robbins (2007: 17) mengemukakan bahwa terdapat tiga faktor yang membentuk sikap kerja, yaitu: a). Kepuasan kerja merupakan sikap umum yang ditunjukkan individu terhadap pekerjaannya. Seseorang dengan tingkat kepuasan kerja tinggi menunjukkan sikap yang positif terhadap pekerjaan itu, sebaliknya seseorang yang tidak puas dengan pekerjaannya menunjukkan sikap yang negatif terhadap pekerjaannya. b). Keterlibatan kerja merupakan tingkat dimana individu mengaitkan dirinya ke pekerjaannya, secara aktif berpartisipasi di dalamnya, dan menganggap kinerjanya penting bagi 
nilai-nilainya. Individu dengan tingkat keterlibatan kerja yang tinggi dengan kuat mengaitkan dirinya ke jenis kerja yang dilakukan dan benar-benar peduli dengan jenis kerja itu. c). Komitmen terhadap organisasi adalah tingkat dimana individu mengaitkan dirinya ke organisasi tertentu dan sasaransasarannya, dan berharap mempertahankan keanggotaan dalam organisasi tersebut. Tingkat komitmen organisasi seorang individu merupakan indikator yang lebih baik mengenai pengunduran diri karyawan daripada indikator kepuasan kerja yang lebih sering digunakan.

2. Guru memiliki motivasi kerja yang baik. Dengan adanya motivasi guru yang baik terdapat hubungan dengan kinerja guru tersebut,, dengan munculnya gairah dalam bekerja disertai beberapa faktor Menurut Ati Cahayani (2003: 61-62) motivasi orang bekerja secara umum diklasifikasikan dalam dua faktor, yaitu : 1) faktor yang dibentuk oleh kebutuhan, keinginan dan harapan yang terdapat dalam diri individu. Misalnya perasaan berprestasi, pengakuan, perasaan kebebasan, dan sikap terhadap pekerjaan dan 2) suatu dorongan yang terdapat dalam diri individu yang mudah dipengaruhi oleh pihak luar. Misalnya gaji, promosi, perlakuan rekan kerja, dan kondisi kerja. Berdasarkan keterangan diatas, faktor yang mempengaruhi motivasi kerja guru terdiri dari faktor internal dan eksternal, termasuk didalamnya adalah keinginan untuk berprestasi, kebebasan dalam melaksanakan tugas, pengakuan, tanggung jawab, gaji, promosi, sikap terhadap pekerjaan, hubungan dengan rekan kerja dan lingkungan kerja.

3. Guru yang bersertifikasi memiliki sikap kerja yang baik dan motivasi kerja yang baik akan mendapat hubungan terhadap hasil kinerja yang dicapai oleh guru tersebut. Syarifuddin (2015: 42) Kinerja yang harus dimilki oleh seorang guru adalah tuntutan atas kemampuannya dalam hal: a). Membuat perencanaan dan persiapan mengajar, b) Menguasai materi pembelajaran, c) Menguasai metode dan strategi mengajar, d) Pemberian tugas-tugas kepada siswa, e) Kemampuan mengelola kelas, f) Kemampuan melakukan penilaian dan evaluasi. Hal tersebut dilakukan oleh guru yang memiliki 
sikap kerja dan motivasi kerja guna mendapatkan hasil yang lebih baik.

\section{KESIMPULAN DAN SARAN}

\section{Kesimpulan}

Berdasarkan hasil penelitian yang telah dilakukan tentang hubungan sikap kerja dan motivasi kerja terhadap kinerja guru yang bersertifikasi se kecamatan panakukang kota makassar, dapat diambil kesimpulan sebagai berikut:

a. Gambaran sikap kerja guru yang bersertifikasi berada pada kategori baik.

b. Gambaran motivasi kerja guru yang bersertifikasi berada pada kategori baik.

c. Gambaran kinerja guru yang bersertifikasi berada pada kategori baik

d. Terdapat hubungan antara sikap kerja guru dengan kinerja guru bersertifikasi di kecamatan panakukang Kota Makassar.

e. Terdapat hubungan antara motivasi kerja guru dengan kinerja guru bersertifikasi di kecamatan panakukang Kota Makassar.

f. Terdapat hubungan antara sikap kerja dan motivasi kerja guru dengan kinerja guru bersertifikasi di kecamatan panakukang Kota Makassar.

\section{Saran}

Berdasarkan hasil penelitian yang telah dilakukan diperoleh hasil bahwa terdapat hubungan sikap kerja dan motivasi kerja dengan kinerja guru yang tersertifikasi se kecamatan panakukang kota Makassar maka dapat diajukan saran-saran yang perlu dipertimbangkan bagi semua pihak yang berkepentingan terkait hasil penelitian adalah sebagai berikut:

1. Bagi kepala dinas pendidikan, kiranya memperhatikaan guru yang tersertifikasi dalam meningkatkan kinerja.

2. Bagi kepala sekolah, kiranya dapat melakukan supervisi pembelajaran dan menjalin kerjasama saling memotivasi yang erat dengan guru dalam pengembangan kinerja di sekolah masing-masing.

3. Bagi guru yang bersertifikasi, kiranya banyak meningkatkan sikap kerja dan motivasi kerja dalam meningkatkan kinerja.

4. Bagi peneliti lainnya, kiranya dapat meneliti lebih jauh tentang hubungan sikap kerja dan motivasi kerja dengan kinerja guru yang bersertifikasi. 


\section{DAFTAR PUSTAKA}

Ametembum. 1997. Kerelevansian GayaGaya Mengajar dan Belajar: Suatu Tinjauan Alnalitik. Bandung: KIPIKIP.

Aniek. $2008 . \quad \underline{\text { http://Klinis }}$ wordpress.com, diakses pada 2307-2016 pukul 16.15

Anwar, S. 2010. Metode Penelitian, Yogyakarta: Pustaka Pelajar.

Arikunto, 2007. Penelitian Kuantitatif. Jakarta. Rajawali

Chaplin, J.P. 1989. Kamus Lengkap Psikologi (Edisi 1 Jilid 1) (Terjemahan Oleh Kartini Kartono). Jakarta: Rajawali.

Dessler, G. 1997. Manajemen Sumber Daya Manusia. Terjemahan Oleh Bunyamin Molan. Jakarta: Rieneka Cipta.

Djamarah, S.B. 2000. Guru dan Anak Didik dalam Interaksi Edukatif. Jakarta: Rieneke Cipta.

Getteng, A,R. 2009. Мепијu Guru Profesional dan Beretika. Yogyakarta: Graha Guru Printika

Goble, F.G. 1993 Psikologi Humanistik Abraham Maslow: Mazhab Ketiga. Yogyakarta: Kanisius.

Hamalik, 2003. Lokakarya Pembinaan Kerikulum Pendidikan Guru. Tidak diterbitkan: UPI Bandung.

Hasibuan, M.S.P. 2006. Organisasi dan Motivasi. Jakarta: Bumi Aksara.

Irianto. A. 2008. Statistik, Konsep Dasar Aplikasi dan Pengembangannya. Jakarta: Enada Media Grup.

Kusmianto, 1997. Motivasi dan Kiatkiatnya. Jakarta: Rieneka Cipta.
Mangkunegara. A.P. 2005. Evaluasi Kerja SDM. Bandung: Refika Aditama.

Martha, I Nengah. 2014. Pengantar Pendidikan. Yogyakarta: Graha Ilmu

Mulyasa. 2003. Kurikulum Berbasis Kompetensi, Konsep karakteristik dan Implementasi. Bandung: Remaja Rosdakarya.

Peraturan Pemerintah Nomor 19 Tahun 2005 Pasal 28 Tentang Guru. Jakarta

Purwanto. 2010. Statistika Untuk Penelitian. Yogyakarta: Pustaka Pelajar.

Rasto, 2003. Menjadi Guru Profesional. Bandung: Remaja Rosdakarya.

....... 2006, Guru dan Pribadinya. Bandung. Remaja Rosdakarya.

Ruki, A. 2002 Sistem Manajemen Kinerja. Jakarta: Gramedia Pustaka Utama.

Robbins, S.P. 2007. Perilaku Organisasi. Jilid 2. Jakarta: Gramedia

Santrock, J.W. 2007. Psikologi Pendidikan (edisi kedua). Jakarta: Prenada Media.

Sardiman, 2006. Guru dan Perubahannya. Jakarta: Rieneka Cipta.

Siagian, S.P. 1995. Kiat Meningkatkan Produktivitas Kerja. Jakarta: Rineke Cipta.

Suardiman. 1991. Psikologi Pendidikan. Yogyakarta: Studing.

Sugiyono. 2011 Statistika Untuk Penelitian. Bandung: Alfabeta.

Supardi. 2013. Kinerja guru. Jakarta: Raja Grafindo Persada. 
Syaiin, S. 2008 Pengaruh Kepuasan Kerja Terhadap Kinerja Pegawai Klinik Spesialis Bestari Medan. (Tesis) Tidak Diterbitkan: Medan Universitas Sumatra Utara.

Syarifuddin. 2015. Pengaruh Kinerja kepala Sekolah dan Keterpenuhan Sarana Prasarana Terhadap Kinerja Guru melalui Motivasi dan Kepuasan Kerja guru SMP Negeri Makassar. Tidak Diterbitkan: Universitas Negeri Makassar.

Undang-Undang Republik Indonesia Nomor 14 Tahun 2005 Tentang Guru dan Dosen dan Peraturan Mendiknas Nomor 16 tahun 2007. Bandung: Citra Umbara.

Wexley. K.N . \& Yuki, G.A. 1992. Prilaku Organisasi dan Psikologi Personalia. Jakarta: Rineka Cipta. 